de la conversion au christianisme (catholicisme et protestantisme) et à l'islamisme; évolution matérielle et psychologique; inter-influence des individus; rôle de l'argent.

\title{
Colonial Students in the United Kingdom and the Irish Republic
}

THE Central Office of Information, London, has published statistics and other factual information concerning colonial students at present studying in the U.K. and the Irish Republic. Of a total of 4,733 students from British Colonial territories, 2,566 come from the African territories, and 2,000 of these from West Africa. Tables show the distribution of these students as between Universities and Medical Schools, Technical and Training Schools, Inns of Court and the nursing profession. A considerable majority falls into the first category. The tables also distinguish between private students and those holding scholarships derived from Colonial Development and Welfare funds, from funds set aside by Colonial Governments, or from funds provided by other bodies.

Responsibility for the administration of scholarships and bursaries, for the placing of students in appropriate educational institutions, and for their personal welfare rests ultimately upon the Director of Colonial Scholars, who is assisted by area officers throughout the country and by liaison officers appointed by Colonial Governments.

The British Council, on behalf of the Colonial Office, undertakes responsibility for meeting colonial students on their arrival in the U.K., arranging accommodation and generally providing for their welfare and entertainment.

\section{Institute on Contemporary Africa, Northwestern University, Summer Session}

A Summer Institute held from 23 June-4 August at Northwestern University, Evanston, Ill,, is designed to bring before as wide a circle as possible the significance of Africa politically, geographically, economically, and culturally. Its purpose is to assist in developing a corps of specialists qualified to interpret contemporary Africa to the American people. Subjects of study include African political problems, cultural traditions, recent history, language problems, the role of missions, education, African art. A seminar on contemporary Africa is conducted by Professor M. J. Herskovits, director of the course and Professor of anthropology, Northwestern University.

\section{Conference of Women Educationists in Kenya}

A Conference held in August I950 in Nairobi to consider the Beecher report on girls' education has presented its report. $\mathrm{I}$ The report is signed by the Chairman, Miss Miriam Janisch, and by representatives of Protestant and Roman Catholic missions. After a reference to the need for emphasizing the qualitative principle in all education, the report gives a brief summary of the development of education of the African girl since 1943 and proceeds to a discussion of the chief proposals made in the Beecher Report relating to domestic science teaching and teacher training. Subsequent sections discuss the different types of schools (Primary, Intermediate, and Secondary) with reference to the form of education offered, the supply of teachers and the provision of equipment. Careers for girls forms the subject of section 3, which includes recommendations relating to the training of nurses and school matrons, and to the establishment of brides' courses. Salary scales, syllabuses, the appointment of woman administrative officers to assist in inspectoral work, and the representation of women educationists on planning committees are dealt with in the concluding sections of this report.

The Hon. Member for Education, in opening the conference, pointed out that it was the first conference of women educationists to be held in the territory.

I Conference of Women Educationists, 15th-17th August, 1950. Govt. Printer, Nairobi, Sh. I. 